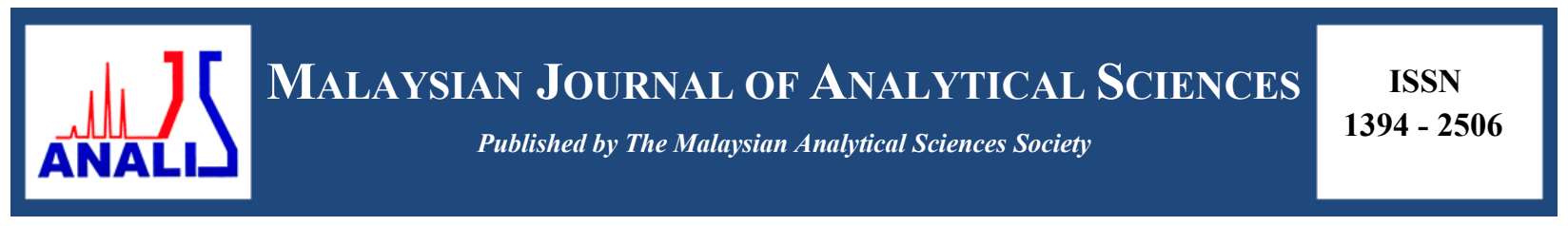

\title{
ANTI-PROLIFERATIVE EFFECT OF Aerva javanica EXTRACTS ON MCF7 AND MDA-MB-231 BREAST CANCER CELL LINES
}

\section{(Kesan Anti-proliferatif Ekstrak Aerva Javanica Ke Atas Titisan Sel Kanser Payudara MCF7 dan MDA-MB-231)}

\author{
Nagla Mustafa Eltayeb ${ }^{1,2}$, Ghada Mustafa Eltayeb ${ }^{3}$, Salizawati Muhamad Salhimi ${ }^{1}$ * \\ ${ }^{1}$ School of Pharmaceutical Sciences, \\ Universiti Sains Malaysia, 11800 USM, Penang, Malaysia \\ ${ }^{2}$ Tropical Medicine Research Institute (TMRI), \\ National Centre for Research (NCR), Khartoum, Sudan \\ ${ }^{3}$ Faculty of Clinical and Industrial Pharmacy, \\ National University-Sudan, Khartoum 11111, Sudan \\ *Corresponding author: saliza@usm.my
}

Received: 16 August 2016; Accepted: 25 July 2017

\begin{abstract}
In this study, the medicinal plant Aerva javanica was sequentially extracted with n-hexane, chloroform and $80 \%$ methanol using maceration technique. The anti-proliferative effect of the three extracts was assessed on two different breast cancer cell lines, MDA-MB-231 and MCF7, using MTT assay. 1, 1-diphenyl-2-picryl-hydrazyl (DPPH) scavenging activity assay was used to assess the antioxidant activity of the three extracts. The result showed that the chloroform extract exerted an inhibitory effect in a concentration dependent manner on both cancer cell lines with $\mathrm{IC}_{50}$ values of $32.7 \pm 0.7 \mu \mathrm{g} / \mathrm{ml}$ and $40.9 \pm 2 \mu \mathrm{g} / \mathrm{ml}$ on MDA-MD321 and MCF7 respectively. 80\% methanol extract exhibited cytotoxic effect on MCF7 with $\mathrm{IC}_{50} \mathrm{value} \mathrm{of} 96.6 \pm 2.9 \mu \mathrm{g} / \mathrm{ml}$, whereas had no cytotoxic effect on MDA-MB-231 cell line $\left(\mathrm{IC}_{50}>200 \mu \mathrm{g} / \mathrm{ml}\right)$. n-hexane extract found to be less cytotoxic against both cancer cell lines with $\mathrm{IC}_{50}$ values of $178.3 \pm 3.7$ and $196.9 \pm 2.8 \mu \mathrm{g} / \mathrm{ml}$ on MDA-MB-231 and MCF7, respectively. The highest $\mathrm{IC}_{50}$ value for scavenging activity was shown by $80 \%$ methanol extract $(46.5 \pm 2.2 \mu \mathrm{g} / \mathrm{ml})$ followed by chloroform extract $(78.3 \pm 3.6 \mu \mathrm{g} / \mathrm{ml})$. On the other hand, the extract prepared in $\mathrm{n}$-hexane showed no scavenging activity effect $\left(\mathrm{IC}_{50}>1000\right.$ $\mu \mathrm{g} / \mathrm{ml})$. Aerva javanica possesses moderate anti-proliferative activity against human breast cancer cell lines with some cytoselectivity towards MDA-MB-231 compare to MCF7 cells. Further studies are needed to identify the potential anticancer component (s) from Aerva javanica.
\end{abstract}

Keywords: MTT assay, Aerva javanica, MCF7, MDA-MB-231

\section{Abstrak}

Dalam kajian ini, tumbuhan ubatan Aerva javanica telah diekstrak secara berturutan dengan n-heksana, kloroform dan $80 \%$ metanol menggunakan teknik pemaseratan. Kesan anti-proliferatif daripada tiga ekstrak dinilai pada dua titisan sel kanser payudara yang berbeza iaitu MDA-MB-231 dan MCF7, menggunakan ujian MTT. Ujian aktiviti hapus sisa DPPH telah digunakan untuk menilai aktiviti antioksidan daripada tiga ekstrak. Keputusan menunjukkan bahawa ekstrak kloroform memberikan kesan perencatan bergantung kepekatan ke atas kedua-dua jenis sel kanser dengan nilai-nilai $\mathrm{IC}_{50} 32.7 \pm 0.7 \mu \mathrm{g} / \mathrm{ml}$ dan $40.9 \pm 2 \mu \mathrm{g} / \mathrm{ml}$ pada MDA-MD-321 dan MCF7 masing-masing. Ekstrak 80\% metanol menunjukkan kesan sitotoksik ke atas MCF7 dengan nilai $\mathrm{IC}_{50} 96.6 \pm 2.9 \mu \mathrm{g} / \mathrm{ml}$, tetapi tidak memberikan kesan sitotoksik ke atas MDA-MB-231 (IC $\left.50>200 \mu \mathrm{g} / \mathrm{ml}\right)$. Ekstrak n-heksana didapati kurang sitotoksik terhadap kedua-dua titisan sel kanser dengan nilai-nilai $\mathrm{IC}_{50} 178.3 \pm 3.7$ dan 196.9 $\pm 2.8 \mu \mathrm{g} / \mathrm{ml}$ masing-masing ke atas MDA-MB-231 dan MCF7. Aktiviti hapus sisa yang tertinggi ditunjukkan oleh ekstrak 80\% metanol $\left(\mathrm{IC}_{50} 46.5 \pm 2.2 \mu \mathrm{g} / \mathrm{ml}\right)$ diikuti dengan ekstrak kloroform $\left(\mathrm{IC}_{50} 78.3 \pm 3.6 \mu \mathrm{g} / \mathrm{ml}\right)$. Berbeza dengan ekstrak n-heksana yang tidak menunjukkan kesan aktiviti hapus sisa $\left(\mathrm{IC}_{50}>1000 \mu \mathrm{g} / \mathrm{ml}\right)$. Aerva javanica mempunyai aktiviti anti-proliferatif 
sederhana terhadap titisan sel kanser payudara manusia dan lebih selektif terhadap sel-sel MDA-MB-231 berbanding MCF7. Kajian lanjut diperlukan untuk nengenalpasti komponen yang berpotensi sebagai anti-kanser daripada Aerva javanica.

Kata kunci: Ujian MTT, Aerva javanica, MCF7, MDA-MB-23

\section{Introduction}

Breast cancer is the most common type of cancer and the main cause of cancer death among women in both developed and developing countries. It accounts for $25 \%$ of all cancer diagnosed cases and $15 \%$ of all cancer female deaths [1]. New advances in research have produced medications for treating different stages of breast cancer. These chemically synthesized agents while being effective, often have some major side effects such as loss of appetite, muscle and joint pain, weakness, dizziness, vaginal bleeding, hair thinning and weight loss. The huge demand for herbal medicines is due to their wide biological activities, higher safety and lower costs [2]. Plants have shown an important role in the development of cancer therapy. Vincristine and vinblastine from Catharanthus roseus and paclitaxel from the bark of the Pacific yew tree, Taxus brevifolia are well known examples of plant-based anticancer drugs [3]. Investigating medicinal plants to explore traditional medicines could lead to the development of novel drugs.

Aerva javanica is a medicinal plant belongs to Amaranthaceae family [4]. It is a perennial herb extensively found in various regions of the tropical world. It is native to Africa, but can also be found in some Asian countries [5]. In Sudan, A. javanica plant or Ras Elshaieb as locally known has been used in traditional medicine in different parts of the country. In North Kordofan Province the plant is used for treating ulcers, wounds, abdominal pain and as antiplasmodial. In the White Nile province, the plant is used against snake bites, breast cancer and rheumatism [6].

Phytochemical analysis studies of A. javanica revealed the presence of different important phytochemical constituents which include flavonoids, alkaloids, triterpenes anthraquinones, coumarins, diterpenes, triterpenes, sterol, saponins, carbohydrates, tannins and polyphenols $[7,8,9]$.

In Sudan, A. javanica, is considered as an important traditional medicinal plant and has been used for treating various diseases, including cancer; however, its anti-cancer properties have not been investigated yet. The main objective of this study was to screen three A. javanica extracts for their cytotoxic effects on MCF7 (estrogenreceptor positive) and MDA-MB-231 (estrogen- receptor negative) breast cancer cell lines and to assess the antioxidant activities of the different extracts.

\section{Reagents and chemicals}

\section{Materials and Methods}

Dulbecco's modified eagle medium (DMEM), fetal bovine serum (FBS), penicillin/streptomycin and trypsin-EDTA were purchased from Gibco, USA. 3-(4,5-Dimethylthiazol-2-yl)- 2,5diphenyl tetrazolium bromide (MTT) reagent, phosphate buffered saline tablets, dimethyl sulfoxide (DMSO) and 1,1-diphenyl-2-picryl-hydrazyl (DPPH) were obtained from Sigma-Aldrich, Germany.

Plant sample collection and identification

The whole plant of Aerva javanica was collected from Nile river banks, state of Khartoum, Sudan, in November 2015. The plant was authenticated by the plant taxonomist Yahya Suliman Mohamed and voucher specimen was deposited in the herbarium of Medicinal and Aromatic Plants Research Institute (MAPRI) - National Center for Research, Khartoum, Sudan.

\section{Plant extraction}

The whole plant was dried under shade for two weeks and then was grounded to make a fine powder. Powdered whole plant (500 g) was macerated sequentially with n-hexane, chloroform and $80 \%$ methanol for 3 days at 50 ${ }^{\circ} \mathrm{C}$. The ratio of raw material to solvent was $1: 10$. The extracts were filtered through Whatmann No. 1 filter paper and concentrated using rotary evaporator at $50^{\circ} \mathrm{C}$, and then all the extracts were put in oven at $50^{\circ} \mathrm{C}$ until complete dryness. The stock solutions of the extract were prepared at $10 \mathrm{mg} / \mathrm{ml}$ and kept at $4{ }^{\circ} \mathrm{C}$ until use. 


\section{Cell culture}

Human breast adenocarcinoma cell lines MCF7 and MDA-MB-231 were originally obtained from American Type Culture Collection (ATCC, Rockville, MD, USA). MCF7 and MDA-MB-231 cells were grown in DMEM supplemented with $10 \%$ fetal bovine serum and $1 \%$ penicillin/streptomycin. All cell lines were incubated in a humidified incubator at $37{ }^{\circ} \mathrm{C}$ under an atmosphere containing $5 \% \mathrm{CO}_{2}$. The cells were sub cultured when nearly confluent using $0.25 \%$ trypsin-EDTA.

\section{Cell viability assay}

Cell viability and proliferation were assessed by MTT (3-[4,5-dimethylthiazol-2-yl]-2,5 diphenyltetrazolium bromide) dye reduction assay. In brief, the cells were seeded in a 96 -well plate $\left(3 \times 10^{3}\right.$ cell/well for MCF7 and $5 \times$ $10^{3} \mathrm{cell} / \mathrm{well}$ for MDA-MB-231) and treated with different concentrations of the extracts $(6.25-200 \mu \mathrm{g} / \mathrm{ml})$ for 48 hours. MTT solution ( $5 \mathrm{mg} / \mathrm{ml}$ in PBS) was added $(20 \mu \mathrm{l} /$ well $)$ and incubated for 3 hours. The formazan crystals formed by the viable cells were dissolved by adding $200 \mu 1 /$ well DMSO. Optical density was measured at $570 \mathrm{~nm}$ wavelength (reference filter $630 \mathrm{~nm}$ ) using an ELISA plate reader (TECAN, sunrise). Cell survival rates were expressed as the percentage of untreated controls, and the $50 \%$ inhibitory concentrations $\left(\mathrm{IC}_{50}\right)$ of the extracts were calculated.

\section{1, 1-diphenyl-2-picryl-hydrazyl (DPPH) free radical analysis}

1,1-diphenyl-2-picrylhydrazyl (DPPH) assay was carried out to evaluate the scavenging activity of the extracts. The stock solution of DPPH was prepared at a concentration of $200 \mu \mathrm{M}$ in absolute methanol while stock solutions of the extracts were prepared at a concentration of $10 \mathrm{mg} / \mathrm{ml} .100 \mu \mathrm{l}$ of DPPH was dispensed in 96-well plate and immediately, $100 \mu \mathrm{l}$ of samples were added at final concentrations of $12.5,25,50,100,200$ and $400 \mu \mathrm{g} / \mathrm{ml}$. Ascorbic acid was used as positive control. Methanol alone and methanol with DPPH were used as blank and negative control, respectively. The mixtures were incubated for 30 minutes in the dark and then the absorbance was measured at $517 \mathrm{~nm}$ using TECAN microplate reader (Tecan sunrise). The dose response curves were obtained and then used to calculate the median inhibitory concentration $\left(\mathrm{IC}_{50}\right)$. The results were expressed as mean $\pm \mathrm{SEM}(\mathrm{n}=$ $6)$.

\section{Statistical analysis}

All of the cytotoxic and antioxidant experiments in the study were carried out for at least three times in triplicate and results were expressed as mean \pm standard deviation (SD). One-way analysis of variance (ANOVA) and Dunnet's Multiple Comparison Test were used to assess $\mathrm{IC}_{50}$ values and cytotoxicity data. $\mathrm{P}<0.05$ was considered as statistically significant.

\section{Extraction}

\section{Results and Discussion}

Extraction efficiencies (\% yield) of the three solvents, $n$-hexane, chloroform and $80 \%$ methanol showed significant differences $(\mathrm{P}<0.05)$. The maximum extraction yield was shown by $80 \%$ methanol $(2.8 \%)$ followed by $\mathrm{n}$-hexane $(1.1 \%)$ and chloroform $(0.6 \%)$. Figure 1 shows the extraction yields of the different solvents.

\section{(4,5-dimethylthiazole-2-yl)-2,5-diphenyl tetrazolium bromide (MTT) assay}

The three extracts exhibited variations in their cytotoxic effect on the two examined breast cancer cell lines with different $\mathrm{IC}_{50}$ values. The chloroform extract showed the lowest $\mathrm{IC}_{50}$ values of $32.7 \pm 0.7$ and $40.9 \pm 2 \mu \mathrm{g} / \mathrm{ml}$ on MDA-MB-231 and MCF7, respectively. $80 \%$ methanol extract exhibited cytotoxic effect on MCF7 with $\mathrm{IC}_{50}$ value of $96.6 \pm 2.9 \mu \mathrm{g} / \mathrm{ml}$, while had no cytotoxic effect on MDA-MB-231 cell line $\left(\mathrm{IC}_{50}>200 \mu \mathrm{g} / \mathrm{ml}\right)$. The n-hexane extract showed high $\mathrm{IC}_{50}$ concentrations for both cancer cell lines (Table 1). 


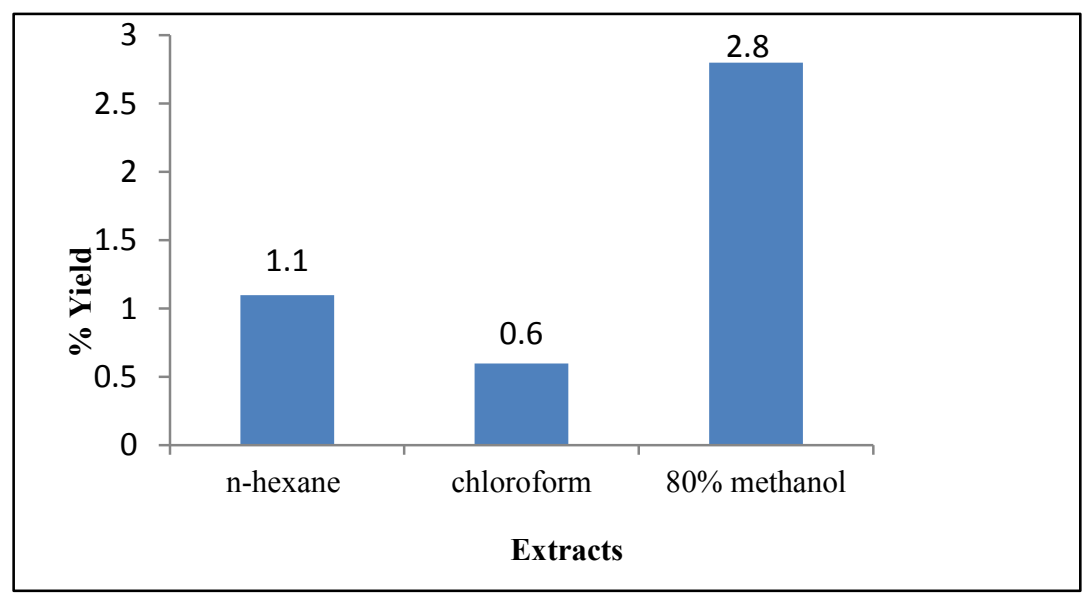

Figure 1. Extraction yields of Aerva javanica using the three different solvents

Table 1. $\mathrm{IC}_{50}(\mu \mathrm{g} / \mathrm{ml})$ values of the three extracts against the two cancer cell lines

\begin{tabular}{lcc}
\hline Extracts & \multicolumn{2}{c}{ IC $_{\mathbf{5 0}}$ value $(\boldsymbol{\mu g} / \mathbf{m l})$} \\
\hline n-Hexane & MCF7 & MDA-MB-231 \\
Chloroform & $196.9 \pm 2.8$ & $178.3 \pm 3.7$ \\
80\% Methanol & $40.9 \pm 2.3$ & $32.7 \pm 0.7$ \\
\hline
\end{tabular}

The results are presented as mean \pm SEM. Each experiment was repeated three times; $(n=3)$

The chloroform extract exerted moderate cytotoxic activity in a concentration dependent manner on both cancer cell lines MDA-MB-231 and MCF7 cell line (Figure 2). Unexpectedly, the cytotoxic effect of the extract was more potent in the highly invasive breast cancer cell line; MDA-MB-231.

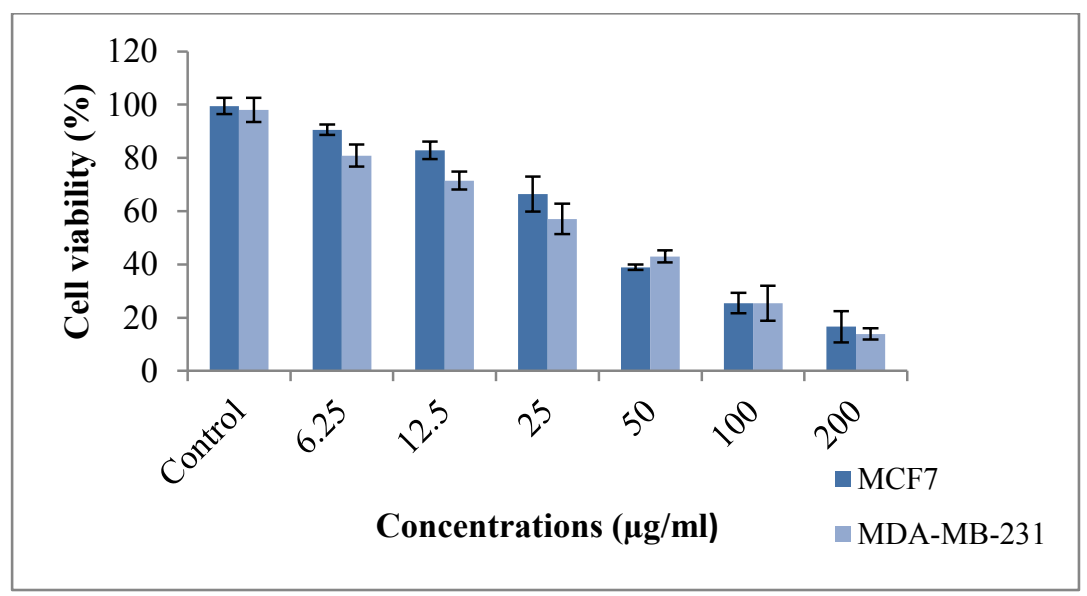

Figure 2. Effect of A. javanica chloroform extract on MDA-MB-231 and MCF7 cell viability. The cells were treated with different concentrations and DMSO as a control for $48 \mathrm{~h}$ and the cell viability was tested using MTT assay 
The pharmacological effects of medicinal plants can be attributed to their main constituents such as alkaloids, flavonoids, coumarins, lignans, saponins and saccharides. Flavonoids are considered as an important phytochemical, with various anti-cancer activities. It has been reported that many flavonoids significantly decrease cancer cell viability via the upregulation of caspase activity [10]. The flavonols, kaempferols and kaempferol glycosides are found in a variety of plants and plant-derived foods $[11,12,13]$. Several reports have shown that kaempferol and/or some kaempferol glycosides induce cell death in a variety of cancer cells from different tissues, including human leukemia cell lines [14] and breast cancer cell lines [15 - 18]. Many flavonol glycosides have been isolated from $A$. javanica as major phytoconstituents [9].

Recently, three kaempferol glycosides have been isolated from A. javanica flowers, namely, kaempferol-3-O-b-D[4000-E-p-coumaroyl-a-L-rhamnosyl $(1 \rightarrow 6)]$-galactoside $\quad(1), \quad$ kaempferol-3-O-b-D-[4000-E-p-coumaroyl-a-L-

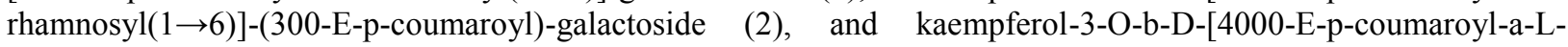
rhamnosyl $(1 \rightarrow 6)$ ]-(400-E-p-coumaroyl)- galactoside (3) [19]. Figure 3 shows the structure of the three acylated flavonoid glycoside compounds isolated from $A$. javanica.

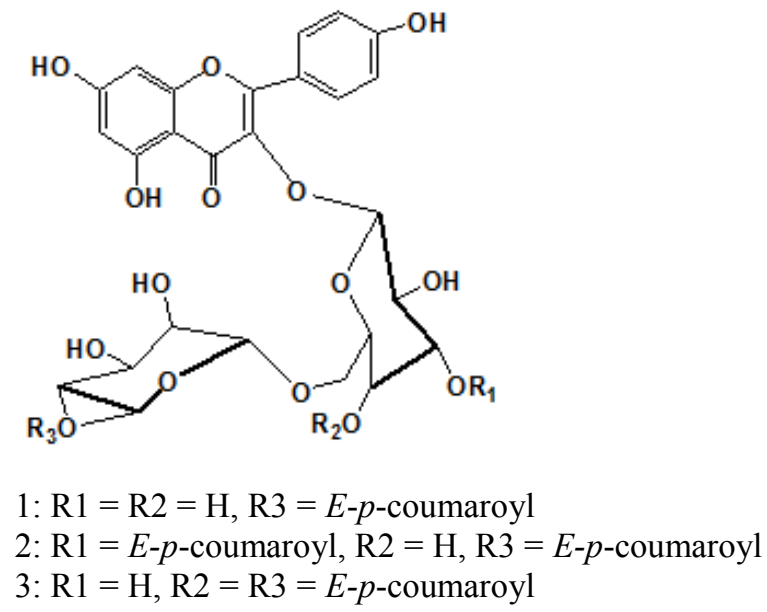

Figure 3. Structure of the three acylated flavonoid glycoside compounds isolated from A. javanica

Coumarins are an important medicinal phytochemicals present in different medicinal plants. Coumarins have a wide range of biological activities including anticancer properties [20]. Both natural and synthetic coumarins exhibited potent anticancer activity against various types of cancer, including breast cancer with low toxicity and good selectivity [20]. Figure 4 shows the coumarin structure. Previous study revealed the presence of coumarins in $A$. javanica chloroform fraction; however, no coumarin compounds have been isolated from the plant yet [8].

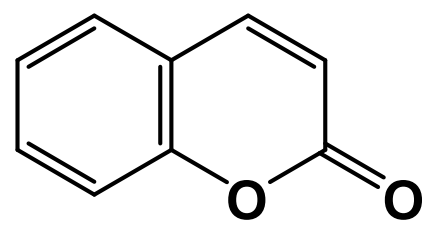

Figure 4. The structure of coumarin

The anti-proliferative effect exhibited by the chloroform extract in this study could be due to the presence of one or both of these important phytochemicals. Further studies are needed to identify the bioactive compounds that present in A. javanica chloroform extract and to elucidate the mechanism of action for these compounds. Our results showed that A. javanica chloroform extract was more cytotoxic to MDA-MB-231 than MCF7 cell line. The 
differences in susceptibility of different tumor cell lines have been shown by several research groups [21, 22, 23]. The differential response of these two cancer cell lines could be due to the differences in their signaling pathway responsible for the cytotoxic effect [23]. It should be noted that the MDA-MB-231 cell line does not express the estrogen receptor [24] and the fact that the extract showed cytotoxic effect on this cell line indicates that estrogenreceptor signaling pathway is not required in its mode of action. This is very interesting since many conventional drugs that are used in the treatment of breast cancer, such as tamoxifen, raloxifene and toremifene require estrogenreceptor to exert their cytotoxic effect [25]. Furthermore, the response of estrogen-receptor negative subtype of breast cancer to conventional drugs is very poor $[24,26]$. The possible molecular mechanisms underlying the differential responses of MCF-7 and MDA-MB-231 cells to the cytotoxic effects of $A$. javanica need to be further investigated.

\section{Antioxidant activity}

The results obtained from DPPH free radical scavenging activity assay in this study showed that the $80 \%$ methanol extract demonstrated the most potent antioxidant activity $(46.5 \pm 3 \mu \mathrm{g} / \mathrm{ml})$ followed by chloroform extract $(78.3 \pm 4$ $\mu \mathrm{g} / \mathrm{ml}$ ), whereas the extract prepared from $\mathrm{n}$-hexane showed poor DPPH scavenging activity as the $\mathrm{IC}_{50}$ value estimated to be more than $1000 \mu \mathrm{g} / \mathrm{ml}$ (Table 2).

Table 2. $\mathrm{IC}_{50}$ values of the three extracts of Aerva javanica evaluated for DPPH scavenging activity

\begin{tabular}{lc}
\hline Extract & DPPH $\left(\mathbf{I C}_{\mathbf{5 0}} \boldsymbol{\mu g} / \mathbf{m l}\right)$ \\
\hline n-Hexane & $>1000$ \\
Chloroform & $78.3 \pm 3.6$ \\
80\% Methanol & $46.5 \pm 2.2$ \\
Ascorbic acid & $3.3 \pm 3.9$ \\
\hline
\end{tabular}

The $80 \%$ methanol extract contains significantly high free radical scavenging activity. Thus, it was found that free radical scavenging activity increased with the increase of the solvent polarity. This observation strongly supports previous results [27] as the methanol extract contains the highest amount of phenolic compounds. Phenolic compounds are known to be powerful antioxidants; they possess scavenging ability due to their hydroxyl groups [28]. So, in the present study, the antioxidant activity of the hydroalchoholic extract was possibly due to its high phenolic content.

\section{Conclusion}

The result of the present study concludes that Aerva javanica shows moderate cytotoxic effect on two different breast cancer cell lines with some cytoselectivity towards MDA-MB-231 compare to MCF7 breast cancer cell line. The plant also exerts moderate free radical scavenging activity. Further studies are needed to identify the potential anticancer component(s) from this medicinal plant and to determine the mechanism(s) of action underlying its cytotoxicity.

\section{Acknowledgement}

We wish to acknowledge Universiti Sains Malaysia (USM) and The World Academy of Sciences (TWAS) for TWAS-USM Postgraduate Fellowship (FR number 3240275091) and financial support to Nagla. Authors also wish to acknowledge Universiti Sains Malaysia for the financial support for this project through RUI grant (1001/PFARMASI/8011003).

\section{References}

1. Torre, L. A., Bray, F., Siegel, R. L., Ferlay, J., Lortet-Tieulent, J. and Jemal, A. (2015). Global cancer statistics, 2012. CA: A cancer journal for clinicians, 65(2): 87 - 108.

2. Khan, M. K., Ansari, I. A. and Khan, M. S. (2013). Dietary phytochemicals as potent chemotherapeutic agents against breast cancer: Inhibition of NF- $\mathrm{KB}$ pathway via molecular interactions in rel homology domain of its precursor protein p105. Pharmacognosy Magazine, 9 (33): 51 - 57. 
3. Cragg, G. M. and Newman, D. J. (2005). Plants as a source of anti-cancer agents. Journal of Ethnopharmacology, 100(1): $72-79$.

4. Khan, M. A., Khan, M. A., Hussain, M. and Mujtaba, G. (2012). Medicinal plants used in folk recipes by the inhabitants of Himalayan region Poonch Valley Azad Kashmir (Pakistan). Journal of Basic and Applied Sciences, 8: $35-45$.

5. Judd, W. S., Campbell, C. S., Kellogg, E. A., Stevens, P. F. and Donoghue, M. J. (1999). Plant systematics: A phylogenetic approach. Ecologia Mediterranea, 25(2): 215.

6. Elsaeed, A., Mohamed, O. S. A. and Ahmed, R., H. (2015). Anti-Inflammatory effects of Aerva Javanica (Burm.f.) Schult. against carrageenan induced paw oedema in albino rats. Journal of forest products \& Industries, 4(1): $17-20$.

7. Radwan, H. M, Nazif, N. M. and Hamdy, A. A. (1999). The lipid and flavonoidal constituents of Aerva javanica (var.bovi) Webb in Hook. F and their antimicrobial activity. Egyptian Journal of Pharmaceutical Sciences, 40: 167 - 178.

8. Abbas, N. O., Ahmed El Imam, Y. M. and Abdelmageed, M. A. M. (2014). The Phytochemical analysis of the ethanolic extract of Sudanese Aerva javanica (Burm.f.) juss. World Journal of Pharmaceutical Research, 4 (6): $2253-2263$.

9. Chawla, P., Chawla, A. M. I. T., Vasudeva, N. E. E. R. U. and Sharma, S. K. (2012). A review of chemistry and biological activities of the genus Aerva-a desert plant. Acta Poloniae Pharmaceutica, 69: 171 - 177.

10. Sepehr, M. F., Jameie, S. B. and Hajijafari, B. (2011). The Cuscuta kotschyana effects on breast cancer cells line MCF7. Journal of Medicinal Plants Research, 5 (27): $6344-6351$.

11. Chen, A. Y. and Chen, Y. C. (2013). A review of the dietary flavonoid, kaempferol on human health and cancer chemoprevention. Food Chemistry, 138(4): 2099 - 2107.

12. Liu, R. H. (2013). Health-promoting components of fruits and vegetables in the diet. Advances in Nutrition: An International Review Journal, 4(3): 384 - 392.

13. Kim, S. H. and Choi, K. C. (2013). Anti-cancer effect and underlying mechanism(s) of kaempferol, a phytoestrogen, on the regulation of apoptosis in diverse cancer cell models. Toxicological Research, 29(4): 229 $-234$.

14. Dimas, K., Demetzos, C., Mitaku, S., Marselos, M., Tzavaras, T. and Kokkinopoulos, D. (2000). Cytotoxic activity of kaempferol glycosides against human leukaemic cell lines in vitro. Pharmacological Research, 41(1): $83-86$.

15. Kang, G. Y., Lee, E. R., Kim, J. H., Jung, J. W., Lim, J., Kim, S. K. and Kim, K. P. (2009). Downregulation of PLK-1 expression in kaempferol-induced apoptosis of MCF-7 cells. European Journal of Pharmacology, 611(1): $17-21$.

16. Kim, B. W., Lee, E. R., Min, H. M., Jeong, H. S., Ahn, J. Y., Kim, J. H. and Cho, S. G. (2008). Sustained ERK activation is involved in the kaempferol-induced apoptosis of breast cancer cells and is more evident under 3-D culture condition. Cancer Biology and Therapy, 7(7): 1080 - 1089.

17. Oh, S. M., Kim, Y. P. and Chung, K. H. (2006). Biphasic effects of kaempferol on the estrogenicity in human breast cancer cells. Archives of Pharmacal Research, 29(5): $354-362$.

18. Tomczyk, M., Drozdowska, D., Bielawska, A., Bielawski, K. and Gudej, J. (2008). Human DNA topoisomerase inhibitors from Potentilla argentea and their cytotoxic effect against MCF-7. Die Pharmazie-An International Journal of Pharmaceutical Sciences, 63(5): 389 - 393.

19. Mussadiq, S., Riaz, N., Saleem, M., Ashraf, M., Ismail, T. and Jabbar, A. (2013). New acylated flavonoid glycosides from flowers of Aerva javanica. Journal of Asian Natural Products Research, 15 (7): 708 - 716.

20. Klenkar, J. and Molnar, M. (2015). Natural and synthetic coumarins as potential anticancer agents. Journal of Chemical and Pharmaceutical Research, 7(7): 1223 - 1238.

21. Jafarian-Dehkordi, A., Emami, S. A., Saeidi, M. and Sadeghi, H. (2004). Cytotoxicologic studies of the extracts of Iranian Juniperus sabina and Platycladus orientalis on Cancer Cells. Journal of Research in Medicinal Sciences, 5: $205-209$.

22. Monajemi, R., Oryan, S., Haeri-Roohani, A., Ghannadi, A. and Jafarian, A. (2005). Cytotoxic effects of essential oils of some Iranian Citrus peels. Iran Journal of Pharmaceutical Research, 3:183 - 187.

23. Jia, T., Zhang, L., Duan, Y., Zhang, M., Wang, G., Zhang, J. and Zhao, Z. (2014). The differential susceptibilities of MCF-7 and MDA-MB-231 cells to the cytotoxic effects of curcumin are associated with the PI3K/Akt-SKP2-Cip/Kips pathway. Cancer cell international, 14 (1): 126 - 140. 
Eltayeb et al: ANTI-PROLIFERATIVE EFFECT OF Aerva javanica EXTRACTS ON MCF7 AND MDA-MB231 BREAST CANCER CELL LINES

24. Brenton, J. D., Carey, L. A., Ahmed, A. A. and Caldas, C. (2005). Molecular classification and molecular forecasting of breast cancer: ready for clinical application? Journal of Clinical Oncology, 23 (29): 7350 - 7360.

25. Department of Health and Human Services. National Institutes of Health, National Cancer Institute, USA. (2012). Hormone therapy for breast cancer. https://cancer.gov/types/breast/breast-hormone-therapy-fact-sheet. [Access online on 20 January 2017].

26. Klinakis, A., Szabolcs, M., Chen, G., Xuan, S., Hibshoosh, H. and Efstratiadis, A. (2009). Igf1r as a therapeutic target in a mouse model of basal-like breast cancer. Proceedings of the National Academy of Sciences, 106(7): $2359-2364$.

27. Munir, H. and Sarfraz, R. A. (2014). Medicinal attributes of Aerva javanica native to pothohar plateau. Pakistan journal of life and social sciences, 12(2): $80-86$.

28. Kähkönen, M. P., Hopia, A. I., Vuorela, H. J., Rauha, J. P., Pihlaja, K., Kujala, T. S. and Heinonen, M. (1999). Antioxidant activity of plant extracts containing phenolic compounds. Journal of Agricultural and Food Chemistry, 47(10): $3954-3962$. 